\title{
Una nueva tentativa, y van tres
}

\section{Jesús Galilea}

Hace 11 años escribí para APUNTS mi último editorial, y hoy los responsables actuales de la publicación me han pedido que contribuya con un editorial más a la nueva y moderna etapa de la revista. ¿Sorpresa? Cuando se rebasa la frontera de los 80 es difícil sentirse sorprendido por algo; si acaso se puede hablar de halago, al ser reclamado para una tarea emprendida en aquel ya lejano 1964, cuando APUNTS era la única revista de medicina del deporte que existía en España, que estuvo presente en la actividad científica del país durante 30 años. Podría decirse que este largo período debería haber sido suficiente para asegurar la supervivencia de una publicación, pero no fue así: imponderables de todo tipo marcaron negativamente su continuidad.

Desde aquel lejano "nacimiento" han pasado muchas cosas y muchos años; valga como muestra inicial el que de la fotocopiadora, el ciclostil y la tradicional linotipia se ha pasado al moderno sistema de revista online-qué pocos recursos les están quedando a las lengua latinas en el nuevo lenguaje de la comunicación-, aunque revindico con la pluma las viejas técnicas de escritura, que ya habrá alguien que las pase al moderno ordenador. Coincidió, por otra parte, APUNTS, con la historia quizá más apasionante de este país, y el reflejo de ella de alguna manera se asomó a sus editoriales.

La vida de APUNTS, como la de otras publicaciones, está hecha de sombras y luces, pero siempre con grandes dosis de ilusión por parte de sus responsables, y de una enorme tozudez. Los que iniciamos el camino sabíamos de la cantidad de obstáculos que nos íbamos a encontrar, aunque quizá no de su altura; contábamos con la penuria económica con que toda publicación científica se enfrenta en nuestro país; éramos conscientes de la indiferencia e incluso del rechazo que íbamos a encontrar entre la "vieja guardia" de la medicina y del deporte. Pero entonces éramos muy jóvenes, con ganas de lucha y todo nos parecía a nuestro alcance.

En efecto, aquella modesta publicación, casi artesanal, se convirtió, con los años, en un revista mundialmente conocida -quizá más al
Coincidió APUNTS con la historia quizás más apasionante de este país, y el reflejo de ella de alguna manera se asomó a sus editoriales. 
otro lado de nuestras fronteras, como ya es habitual-, y punto de referencia de cuanto en nuestro país se investigaba en medicina del deporte. Fue tanta su fecundidad y precocidad que de ella nació otra revista en el INEF de Barcelona: Apunts d'Educació Física $i$ Esport, que goza ya de 21 años de historia, de una espléndida realidad actual y de un esperanzado futuro.

Como decía con anterioridad, su continuidad en el tiempo no fue precisamente un camino de rosas para APUNTS; su dependencia económica de la Administración la hizo pasar por momentos difíciles a tenor de los cambios en ésta. No gozó del reconocimiento al que se hizo justamente merecedora, y se llegó a la pintoresca situación de ser "descubierta" por algunos después de 30 años de existencia, y por último, se la dejó morir sin el menor interés por salvarla.

Pasados los años, ha habido, sí, esporádicos intentos por reavivarla por parte de algunos compañeros que vivieron los últimos tiempos de la revista, pero sus generosas intenciones, imagino, tropezaron con la misma indiferencia que nosotros sufrimos. Bien, ahora parece ser que una nueva tentativa, en esta ocasión apoyada por la empresa privada, pretende resucitar y dar continuidad a algo que nunca debió morir con tan pocos honores.

Deseo y espero que este editorial sirva para reavivar las cenizas de aquella vieja revista nacida en año olímpico y que a sus actuales responsables les ilumine la antorcha de la ilusión y el tesón, y que los malos vientos no la apaguen. 